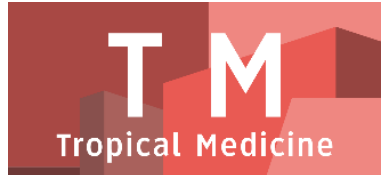

PAPER - OPEN ACCESS

\title{
Kajian Etnobotani Tumbuhan Obat pada Masyarakat Blang Bungong Kecamatan Tangse Kabupaten Pidie-Aceh
}

\author{
Author : Ernilasari \\ DOI $\quad: 10.32734 /$ tm.v1i3.258 \\ Electronic ISSN : 2623-0542 \\ Print ISSN : 2623-0550
}

Volume 1 Issue 3 - 2018 TALENTA Conference Series: Tropical Medicine (TM)

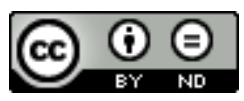

This work is licensed under a Creative Commons Attribution-NoDerivatives 4.0 International License.

Published under licence by TALENTA Publisher, Universitas Sumatera Utara
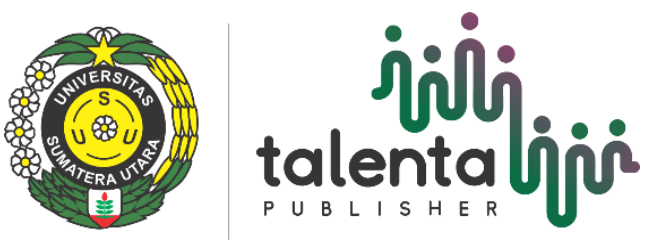


\title{
Kajian Etnobotani Tumbuhan Obat pada Masyarakat Blang Bungong Kecamatan Tangse Kabupaten Pidie-Aceh
}

\author{
Ernilasari $^{\mathrm{a}^{*}, \text { Saudah }^{\mathrm{b}}, \text { Mulia Aria Suzanni }}{ }^{\mathrm{c}}$, Diana $^{\mathrm{d}}$, Irhamni $^{\mathrm{e}}$, \\ Vera Viena ${ }^{\mathrm{f}}$ \\ ${ }^{a b}$ Mahasiswa Magister Biologi FMIPA Universitas Syiah Kuala; \\ ${ }^{c}$ Akademi Analis Farmasi dan Makanan Banda Aceh; \\ ${ }^{d}$ Mahasiswa Magister Kimia FMIPA Universitas Syiah Kuala; \\ ${ }^{e f}$ Fakultas Teknik Universitas Serambi Mekkah \\ ernilasari@serambimekkah.ac.id
}

\begin{abstract}
Abstrak
Telah dilakukan penelitian tentang kajian etnobotani pada masyarakat Blang Bungong kecamatan Tangse Kabupaten Pidie-Aceh. Penelitian ini bertujuan untuk mengidentifikasi dan menginventarisasi pemanfaatan tanaman obat oleh masyarakat Desa Blang Bungong di kabupaten Pidie Aceh. Tujuan khusus dalam penelitian ini adalah untuk mengetahui jenis tanaman yang digunakan, bagian yang digunakan, cara menggunakan tumbuhan, cara mendapatkan, serta penyakit yang diobati. Metode yang digunakan adalah metode Participatory Rural Appraisal (PRA), yaitu proses penilaian yang berorientasi pada keterlibatan dan peran masyarakat dalam penelitian. Sampel penelitian ini adalah dukun tradisional, dan masyarakat Blang Bungong. Tumbuhan yang digunakan sebagai obat oleh masyarakat Blang Bungong sebanyak 25 spesies yang tersebar dalam 19 famili. Bagian tumbuhan yang paling sering digunakan adalah daun. Tumbuhan obat didapatkan masyarakat berasal dari tumbuham liar dan budidaya. Penyakit diobati umumnya adalah penyakit ringan seperti flu, demam dan batuk.
\end{abstract}

Kata Kunci: Etnobotani, Tumbuhan Obat, Blang Bungong, Pidie, Aceh

\begin{abstract}
A study of ethnobotany has been conducted on Blang Bungong society, Tangse Sub-district, Pidie District, Aceh. This research aims for identify and inventory the utilization of medicinal plants by Blang Bungong Village in Pidie Aceh district. Specific objective in this research is to know the type of plants used, the part used, how to use plants, how to get, and the disease treated. Research method used are Participatory Rural Appraisal (PRA), which is an assessment process oriented to the involvement and role of the society in research. The sample of this research is village shaman, and Blang Bungong society. Plants used as medicine by the Blang Bungong society as 25 species spread in 19 families. The most commonly used plant part is the leaves. Medicinal plants obtained by the community came from wild grow and cultivation. Diseases treated are generally minor ailments such as flu, fever and cough.
\end{abstract}

Keywords: Etnobotany, Medicinal Plant, Blang Bungong, Pidie, Aceh

\section{Pendahuluan}

Indonesia merupakan negara 'mega biodiversity' yang mempunyai kekayaan flora dan fauna berlimpah termasuk tumbuhan obat. Hal ini didukung oleh kondisi Indonesia yang beriklim tropis dan mempunyai tumbuhan yang 
beranekaragam. Sekitar 30.000 jenis tumbuhan yang sudah terdata di Indonesia, 9.606 jenis (32.02\%) diantaranya merupakan tumbuhan obat[1].

Penduduk Indonesia menggunakan tumbuhan sebagai obat alami sejak lama, Salah satu masyarakat yang masih mempertahankan tradisi penggunaan bahan alam sebagai obat adalah masyarakat Blang Bungong kecamatan Tangse di Kabupaten Pidie. Blang Bungong merupakan daerah pedesaan dengan kondisi hutan yang tergolong masih alami. Kekayaan pengetahuan pemanfaatan tumbuhan obat ini diwariskan secara turun temurun [2].

Pewarisan pengetahuan tumbuhan obat dilakukan hanya secara lisan dan belum didata dan didokumentasikan secara ilmiah. Jika tidak didokumentasikan dengan baik dikhawatirkan pengetahuan ini akan mulai terkikis seiring hilangnya habitat alami yang menyebabkan punahnya tumbuhan obat. Ditambah lagi seiring dengan semakin banyaknya bermunculan penyakit-penyakit baru dan belum ditemukannya obat yang bisa menyembuhkan, maka kajian etnobotani tumbuhan obat perlu dilakukan. Salah satunya adalah di Desa Blang Bungong Kecamatan Tangse Kabupaten Pidie-Aceh. Penelitian ini diharapkan dapat memberikan informasi baru tentang pengetahuan etnobotani tumbuhan obat pada masyarakat Blang Bungong Kecamatan Tangse Kabupaten Pidie-Aceh

\section{Bahan dan Metode}

Penelitian ini dilakukan di Blang Bungong kecamatan Tangse Kabupaten Pidie-Aceh. Metode yang dilakukan dalam pengambilan data adalah Participatory Rural Appraisal (PRA), yaitu proses pengkajian yang berorientasi pada keterlibatan dan peran masyarakat secara aktif dalam penelitian [3]. Wawancara dilakukan pada masyarakat Blang Bungong Kabupaten Pidie. Pemilihan sampel dilakukan secara purposive sampling. Penduduk yang diwawancarai adalah masyarakat dan pengobat (dukun) yang tinggal di Blang Bungong Kabupaten Pidie.

\section{Hasil Dan Pembahasan}

Berdasarkan hasil penelitian yang dilakukan di desa Blang Bungong kecamatan Tangse Kabupaten Pidie, didapatkan 25 spesies tumbuhan yang digunakan sebagai obat yang tersebar kedalam 19 family (Tabel 1).

Tabel 1. Jenis Tumbuhan Obat yang digunakan oleh Masyarakat Blang Bungong Kecamatan Tangse kabupaten Pidie-Aceh

\begin{tabular}{|c|c|c|c|c|c|c|}
\hline No & Famili & Nama Ilmiah/umum & $\begin{array}{l}\text { Bagian yang } \\
\text { digunakan }\end{array}$ & Habitat & Cara penggunaan & Manfaat \\
\hline 1 & Acanthaceae & $\begin{array}{l}\text { Andrographis } \\
\text { paniculatal } \\
\text { Sambiloto }\end{array}$ & Daun & Liar & Direbus & Obat malaria \\
\hline 2 & Amaryllidaceae & $\begin{array}{l}\text { Allium cepal } \\
\text { Bawang merah }\end{array}$ & Umbi & Budidaya & Digeprek & Obat masuk angin \\
\hline 3 & Anarcadiaceae & $\begin{array}{l}\text { Lannea } \\
\text { coromandelica } \\
\text { Kuda-kuda }\end{array}$ & Kulit batang & Liar & Direbus & $\begin{array}{l}\text { Campuran ramuan obat pasca } \\
\text { melahirkan }\end{array}$ \\
\hline 4 & Apiceaae & $\begin{array}{l}\text { Cuminum cyminum/ } \\
\text { Jintan puith }\end{array}$ & Biji & Budidaya & Ditumbuk & $\begin{array}{l}\text { Campuran obat pasca melahirkan } \\
\text { dan obat sakit kepala }\end{array}$ \\
\hline 5 & Apocynaceae & $\begin{array}{l}\text { Parameria pichon/ } \\
\text { On Suerapat }\end{array}$ & Daun & Liar & Direbus & Pasca melahirkan \\
\hline 6 & Arecaceae & $\begin{array}{l}\text { Acorus calamus/ } \\
\text { Jeurangau }\end{array}$ & Rimpang & Budidaya & Ditumbuk & $\begin{array}{l}\text { Campuran obat pasca melahirkan } \\
\text { dan kejang pada anak }\end{array}$ \\
\hline 7 & Arecaeae & $\begin{array}{l}\text { Areca catechu/ } \\
\text { Pinang }\end{array}$ & Buah & Liar & Digiling & $\begin{array}{l}\text { Jus pinang muda untuk } \\
\text { meningkat kan stamina }\end{array}$ \\
\hline 8 & Asteraceae & $\begin{array}{l}\text { Blumea balsamiferal } \\
\text { Capa }\end{array}$ & Daun & Liar & Direbus & $\begin{array}{l}\text { Campuran untuk ramuan pasca } \\
\text { melahirkan, malaria }\end{array}$ \\
\hline
\end{tabular}




\begin{tabular}{|c|c|c|c|c|c|c|}
\hline 9 & Asteraceae & $\begin{array}{l}\text { Chromalaena } \\
\text { odoratal } \\
\text { Rapoh atot }\end{array}$ & Daun & Liar & Diremas & Obat luka \\
\hline 10 & Asteraceae & $\begin{array}{l}\text { Eclipta alba } \mathrm{L} / \\
\text { Urang Aring }\end{array}$ & Daun & Liar & Digiling & $\begin{array}{l}\text { Demam, campuran obat pasca } \\
\text { melahirkan }\end{array}$ \\
\hline 11 & Basellaceae & $\begin{array}{l}\text { Anredera cordifolial } \\
\text { Binahong }\end{array}$ & Daun & Liar & Ditumbuk, direbus & Obat luka luar, kolesterol \\
\hline 12 & Caricaeae & $\begin{array}{l}\text { Carica papayal } \\
\text { Pepaya }\end{array}$ & $\begin{array}{l}\text { Daun, biji, } \\
\text { bunga }\end{array}$ & Budidaya & $\begin{array}{l}\text { Diremas, ditumbuk, } \\
\text { di giling halus, di } \\
\text { rebus }\end{array}$ & $\begin{array}{l}\text { Daun dan bunga untuk malaria } \\
\text { dan penambah darah, Biji } \\
\text { digunakan untuk diare }\end{array}$ \\
\hline 13 & Crassulaceae & $\begin{array}{l}\text { Kalanchoe } \\
\text { laciniata/Sesejuk }\end{array}$ & Daun & Liar & Digiling & Obat bisul dan demam \\
\hline 14 & Euphorbiaceae & $\begin{array}{l}\text { Macaranga tanrius/ } \\
\text { Seribu Guna }\end{array}$ & Daun & Liar & $\begin{array}{l}\text { Digiling, ditumbuk, } \\
\text { direbus }\end{array}$ & Obat kolesterol \\
\hline 15 & Fabaceae & $\begin{array}{l}\text { Abrus prekatorius/ } \\
\text { Saga }\end{array}$ & Daun & Liar & Diremas & $\begin{array}{l}\text { Perasan air daun saga untuk obat } \\
\text { batuk }\end{array}$ \\
\hline 16 & Fabaceae & $\begin{array}{l}\text { Caesalpinea } \\
\text { pulcherrimal } \\
\text { on meurak }\end{array}$ & Daun & Liar & Diperas & Obat batuk, panas dalam \\
\hline 17 & Myrtaceae & $\begin{array}{l}\text { Syzygium } \\
\text { polyanthum/ } \\
\text { On Salam }\end{array}$ & Daun & Liar & Direbus & Anti diabetes \\
\hline 18 & Phyllanthaceae & $\begin{array}{l}\text { Phyallanthus } \\
\text { pulcher/On } \\
\text { Bangguri }\end{array}$ & Daun & Liar & Ditempel & Campuran obat sakit kepala \\
\hline 19 & Piperaceae & $\begin{array}{l}\text { Piper nigrum } \mathrm{L} / \\
\text { Lada }\end{array}$ & biji & Budidaya & Ditumbuk & $\begin{array}{l}\text { Campuran obat sakit kepala dan } \\
\text { obat pasca melahirkan }\end{array}$ \\
\hline 20 & Rutaceae & $\begin{array}{l}\text { Citrus aurantifolia } \\
\text { Jeruk nipis }\end{array}$ & Buah & Liar & Diperas & Obat batuk \\
\hline 21 & Simaroubaceae & $\begin{array}{l}\text { Eurycoma } \\
\text { longifolial } \\
\text { On Tungkat Ali }\end{array}$ & $\begin{array}{l}\text { Daun dan } \\
\text { akar }\end{array}$ & Liar & Direbus & $\begin{array}{l}\text { Rebusan daun untuk obat } \\
\text { demam,stamina pasca } \\
\text { melahirkan, }\end{array}$ \\
\hline 22 & Thymelaeaceae & $\begin{array}{l}\text { Phaleria } \\
\text { macrocarpal } \\
\text { Mahkotadewa }\end{array}$ & $\begin{array}{l}\text { Buah (kulit } \\
\text { buah) }\end{array}$ & Budidaya & $\begin{array}{l}\text { Direbus setelah } \\
\text { dikeringkan }\end{array}$ & Obat jantung dan kolesterol \\
\hline 23 & Zingiberaceae & $\begin{array}{l}\text { Curcuma longa/ } \\
\text { Kunyit }\end{array}$ & Rimpang & Budidaya & Ditumbuk & $\begin{array}{l}\text { Campuran obat pasca melahirkan } \\
\text { dan obat flu untuk anak }\end{array}$ \\
\hline 24 & Zingiberaceae & $\begin{array}{l}\text { Zingiber officinalel } \\
\text { Jahe }\end{array}$ & Rimpang & Budidaya & Direbus & $\begin{array}{l}\text { Obat masuk angin dan pegal- } \\
\text { pegal }\end{array}$ \\
\hline 25 & Zingiberaceae & $\begin{array}{l}\text { Curcuma } \\
\text { zanthorrhizal } \\
\text { Temulawak }\end{array}$ & Rimpang & Budidaya & Ditumbuk & Penambah nafsu makan \\
\hline
\end{tabular}


Hasil penelitian diatas menunjukkan famili yang paling banyak digunakan sebagai obat adalah Asteraceae dan Zingiberaceae, masing-masing terdiri dari 3 spesies. Zingiberaceae secara umum lebih dikenal dengan kelompok tumbuhan temu-temuan yang mengandung minyak yang dapat menguap dan berbau aromatik [4]. Famili ini merupakan tumbuhan budidaya yang paling sering dijumpai di Indonesia, karena selain digunakan sebagai obat, famili ini merupakan salah satu bumbu dapur khas Indonesia. Kunyit mengandung zat kimia yang berfungsi untuk mengobati penyakit yang sebagian besar disebabkan oleh bakteri, virus maupun yang sejenisnya [5]. Kunyit mengandung senyawa kurkumin yang dapat mempercepat re-epitelisasi, poliferasi sel dan sintesis kolagen [6], sehingga mampu mempercepat penyembuhan luka terutama pada perawatan ibu pasca melahirkan.

Bagian tumbuhan yang paling sering digunakan adalah daun. Sementara buah hanya digunakan pada tumbuhan mahkota dewa. Bagian lainnya berupa bunga, kulit batang, akar maupun rimpang akar. Banyaknya pengunaan bagian daun selain karena memiliki banyak fungsi/khasiat, daun juga merupakan bagian yang paling mudah diambil dan ditemukan kapan saja diperlukan, berbeda pada bagian tumbuhan obat yang lain yang biasanya tergantung musim misalnya pada bagian bunga maupun buah [7].

Umumnya tumbuhan yang digunakan merupakan tumbuhan liar baik yang tumbuh di dalam hutan maupun pinggir jalan. Namun ada beberapa tumbuhan yang merupakan tumbuhan budidaya yang didapat dari kebun dan pekarangan rumah seperti family Zingiberaceae.

Pengobatan umumnya dilakukan dengan cara diminum karena dianggap lebih efektif dalam menyembuhkan penyakit. Sementara pengolahannya paling banyak dilakukan dengan cara direbus bagian tumbuhan yang akan digunakan, baik dikeringkan terlebih dahulu (simplisia) maupun langsung bagian tumbuhan yang masih segar. Penggunaan cara rebusan dianggap lebih hemat karena bisa digunakan secara berulang. Dalam pemanfaatannya tumbuhan obat tersebut diramu secara tunggal maupun dicampur dengan tumbuhan lainnya.

Adapun penyakit yang sering diobati umumnya merupakan penyakit ringan seperti flu, demam, sakit kepala, batuk, masuk angin, pegal-pegal, bisul, diare, dan luka ringan. Sementara penyakit lainnya berupa malaria, kolesterol, jantung, diabetes, serta sebagai obat pasca melahirkan.

\section{Kesimpulan}

Berdasarkan hasil penelitian, didapatkan 25 spesies tumbuhan yang digunakan sebagai tumbuhan obat oleh masyarakat Blang Bungong kecamatan Tangse kabupaten Pidie-Aceh. Bagian tumbuhan yang digunakan berupa akar, rimpang akar, batang, daun, buah dan bunga. Sementara penyakit yang sering diobati adalah penyakit ringan.

\section{Ucapan Terima Kasih}

Penulis mengucapkan terimakasih kepada Kemenristekdikti yang telah membantu mendanai penelitian ini, LPPM Universitas Serambi Mekkah dan Universitas Serambi Mekkah.

\section{Daftar Pustaka}

[1] Kinho, J., Arini, D.I.D., Halawane, J., Nuraini, L., Halidah, Kefiar, Y., Karundeng, M.C. (2011). Tumbuhan Obat Tradisional di Sulawesi Utara Jilid II. Balai Penelitian Kehutanan Manado, Badan Penelitian dan Pengembangan Kehutanan, Kementerian Kehutanan, Manado, Indonesia. Halaman 1.

[2] Murni. S. A., P. Prawito., S. Widiono. (2012). Eksistensi Pemanfaatan Tanaman Obat Tradisional (TOT) Suku Serawai Diera Medikalisasi Kehidupan. Jurnal Penelitian Pengelolaan Sumberdaya Alam dan Lingkungan, 1(3). Halaman 225-233.

[3] Nasution, J. (2009). Oukup, Ramuan Tradisional Suku Karo Untuk Kesehatan Pasca Melahirkan: Suatu Analisa Bioprospeksi Tumbuhtumbuhan Tropika Indonesia. Tesis. Institut Pertanian Bogor.

[4] Auliani, A., Fitmawati, Sofiyanti, N. (2014). Studi Etnobotani Famili Zingiberaceae Dalam Kehidupan Masyarakat Lokal Di Kecamatan Siak Hulu Kabupaten Kampar, JOM FMIPA, 1(2). Halaman: 526-533.

[5] Kuntorini, E.M. (2005). Botani Ekonomi Suku Zingiberaceae sebagai Obat Tradisional oleh Masyarakat di Kotamadya Banjarbaru. Bioscientiae, 2 (1). Halaman 25-36.

[6] Wientarsih, I., Winarsih, W., Sutardi, N.L. (2012). Aktivitas Penyembuhan Luka oleh Gel Fraksi Etil Asetat Rimpang Kunyit pada Mencit Hiperglikemik. Jurnal Veteriner. 13(3). Halaman: 251-256.

[7] Efremila, Wardenaar, E., Sisillia, L. (2015). Studi Etnobotani Tumbuhan Obat oleh Etnis Suku Dayak di Desa Kayu Tanam Kecamatan Mandor Kabupaten Landak. Jurnal Hutan Lestari, 3 (2). Halaman:234-246 